\title{
Globalization and State-Society Relations in Africa
}

\author{
Kidane Mengisteab*
}

\begin{abstract}
The post-colonial African state has long been viewed as a major culprit in Africa's socioeconomic crisis. Its failure to coordinate policy with broad social interests and to reconcile its governance system with the institutions and cultural values of its citizens is a major factor. This paper examines if new globalization and its liberalization policies have begun to narrow the discrepancy between policy and social interests and to facilitate the reconstitution of the state by shifting the balance of power between state and society in favor of society. The findings suggest that, despite the apparent spread of democratization during the era of post-Cold-War globalization, the policy mechanisms of globalization have notably worsened the disjuncture between policy and social interests and exacerbated the antagonisms between the state and society in the African continent.
\end{abstract}

\section{Résumé}

L'Etat africain post-colonial a longtemps été perçu comme étant principalement coupable de la crise socioéconomique qui frappe l'Afrique. Son incapacité de coordonner la politique et les intérêts sociaux de la population et d'adapter son système de gouvernance aux institutions et valeurs culturelles de ses citoyens en est un facteur majeur. Ce document examine la question de savoir si la nouvelle mondialisation, ainsi que ses politiques basées sur le libéralisme économique, ont commencé à réduire l'écart qui existe entre les politiques et les intérêts sociaux et à faciliter la reconstitution de l'Etat en contrebalançant le rapport de force qui existe entre l'Etat et la société en faveur de la société. Les résultats révèlent que même s'il est apparent que le processus de démocratisation n'a

* Department of African and African American Studies, Pennsylvania State University, University Park, PA 16802, USA. 
cessé de gagner du terrain depuis le commencement de l'ère de la globalisation post guerre froide, les mécanismes politiques globalisants ont considérablement aggravé la disjonction entre la politique et les intérêts sociaux et ont exacerbé les antagonismes entre l'Etat et la société en Afrique

\section{Conceptualizing globalization}

While globalization is a highly contested concept, it is widely viewed to involve a process of rapid intensification of economic, political, and cultural interconnectedness among the different actors and geographic areas in the global system. The forces that unleash globalization are also in dispute. There is little doubt that market forces play a significant role since expansion of markets worldwide is inherent to the capitalist socioeconomic system, in which production is primarily geared for exchange. Technological advancement, especially in the areas of communication and transportation, also facilitates the process. These two 'generic' (Sklair 2006: 30) factors are not new, however, and they do not explain the outburst of globalization, especially since the end of the Cold War. Two hegemonic forces or conditions provide a fuller explanation. One is a high level of concentration of global political (military) and economic power culminating in the rise of a dominant (hegemonic) state. Another condition is a balance of power among social classes, which is decisively tilted in favor of capital, especially transnational capital, at the global level. The confluence of these two conditions sets in motion episodes of the capitalist system that are characterized by a hyperdrive for accumulation of capital and accumulation of power. To facilitate the attainment of these two goals, the hegemonic power, along with powerful capital, promotes the vision of integration of national economies into a single economic space through various mechanisms, in a pattern of direct colonialism in the nineteenth century and institutional arrangements and liberalization policies in the twenty-first century.

The kinds of configuration of power among states and the balance of power among social classes that make the rapid integration of the global system under a liberal ideology possible are not always present. Capitalism is, thus, not always characterized by the broad globalization that has unfolded in either the post-Cold War era or the one that prevailed in the nineteenth century roughly between 1840 and 1914. Globalization of the nineteenth century (henceforth old globalization) was established largely under the political and economic hegemony of Great Britain and it incorporated areas outside of Western Europe and North America largely through imperialism and often through direct colonialism. The rise of powers that challenged British hegemony by the end of the nineteenth century and the beginning of the twentieth century culminated in the world wars, which, in conjunction 
with broad social struggle against the dominance of capital, brought changes in the global configuration of power and in the balance of power among social classes and thereby the end of old globalization.

Another cycle of globalization (new globalization) has unfolded since the closing decades of the twentieth century after an interlude of roughly 75 years, which were largely dominated by episodes of the welfare state system and socialism. These two social systems reflected the relative ascendancy of working-class influence in global politics and the emergence of contending superpowers and competing ideologies.

Like old globalization, new globalization is projected by a new political and economic hegemony accompanied by the ascendancy in the power of the capitalist class relative to other social classes. Opinions on the nature of the new hegemony vary widely in the literature. One view suggests that the US, which is in a position to influence other powers to act in conformity with its leadership, represents the new hegemonic power and that globalization is a reflection of US dominance of the global system (Waltz 1999). Another perspective contends that the new hegemony is not state-based but rather composed of a decentralized transnational elite (Hardt and Negri 2000; Robinson 2004). It is unclear how the transnational elite are able to exercise and sustain global hegemony without the direct control of military power. Nevertheless, despite the differences in the interpretation of the nature of the hegemony, it is widely recognized that the new global order is projected by a new political, economic, and ideological hegemony.

The resurgence in the power of capital is also evident from a number of developments, including deregulation of capital mobility, which have facilitated the rise of a transnational capitalist class and enhanced capital's bargaining power vis-à-vis states (especially the less powerful ones) and labor. The growing influence of capital over policy, including expenditures on social services, regulatory measures, and tax policies is another indicator of the upsurge in the power of capital. Some studies have shown that capital's interests coincide with smaller government and lower taxes while labor prefers higher taxes and state provision of greater public services (Findlay and Wellisz 2003). The disproportionate remuneration of capital relative to its contribution to productivity, while wage rates have fallen below rates of economic growth at least in the OECD countries (which have reliable data), is another reflection of the surge in the power of capital (OECD 1997-2000; Rupert 2000: 41). The weakening of labor movements, partly through deregulation of labor markets and partly through reorganization of work, which is propelled by rapid technological advance, is another indicator of the shift in the balance of power among social classes in favor of capital. 
The relative weakness of US economic and technological dominance has led to suggestions that the US hegemony is on the decline (Wallerstein 2004). Others suggest that the decline in economic profitability and crisis of legitimacy of its leadership account for the weakening of US hegemony (Brenner 1998; Silver and Arrighi 2005). The inability of the US to suppress wars of insurgency, such as those in Iraq and Afghanistan, is likely to bolster the view of the decline. In any case, the suggestion of the decline of US hegemony does not refute its presence. Rather it raises questions about the sustainability of the hegemony and that of globalization, which is projected by the hegemony.

Unlike old globalization, new globalization has unfolded without direct state-based colonialism. Instead, the new hegemonic power or 'Empire', as referred to by Hardt and Negri (2000), mostly utilizes institutional arrangements and policy instruments as mechanisms of globalization or conditions for integration with the global economy, although economic sanctions and even force are also applied when deemed necessary. The policy-based mechanisms of globalization largely rest on creating an open global economy through liberalization of trade and mobility of capital, restrictive fiscal and monetary policies, including those that cover taxes, public spending, interest rates, and foreign exchange rates, and retrenchment of state involvement in economic activity, including its redistributive and regulatory measures. In addition to promoting capital accumulation, these globalization mechanisms facilitate the distribution of economic benefits among geographic areas and social classes on the basis of access to and control of capital. A brief discussion of Africa's incorporation into the global system follows so that our analysis of the impacts of new globalization on state-society relations in Africa is placed within a historical context.

\section{Africa's incorporation into the global system}

Whether the hegemonic power is a provider of global leadership, by establishing a path of development and the rules governing the state system for the advancement of interests beyond its own, or merely represents an imperialist domination has been a subject of debate (Bienefeld 1994; Chase-Dunn 1994; Amin 2001; Petras and Veltmeyer 2001; Silver and Arrighi 2005). Even if it is a provider of leadership, however, the development path and rules of the state system it sets up are likely to have different impacts on different countries. It is thus possible for the hegemonic power to project characteristics of both leadership and imperialist domination at the same time. It is often to the interest of the hegemonic power to extend the benefits of its position to potential contenders (secondary powers) in an effort to thwart any collusion among them for purposes of challenging its power. It does 
not, however, need to extend any benefits to weak states that pose little threat to its hegemony, although it may also pursue policies of differential treatment towards weak states. Moreover, it is likely that the narrower the power-gap between the hegemonic power and the secondary powers is, the more imperialistic the hegemonic power becomes towards the weak states. The need for increasing profit rates to fortify its economic power and to display its military power to potential contenders may lead the hegemonic power to take a more aggressive imperialist posture towards weak states. In this way hegemony can represent leadership to some and sheer domination to others.

In any case, the experience of Africa's incorporation into the global capitalist system gives little reason not to view hegemony as imperialist domination. While specifying the precise dates for each phase is difficult, at least four different phases of incorporation of the continent into the global economic system can be identified. The first phase occurred roughly between the middle of the fifteenth century and the middle of the nineteenth century. This phase itself had at least two stages, including the early commercial incorporation and the pillage of the continent during the era of the slave trade, between 1500 and 1890, when roughly 22 million slaves were exported out of the continent (Ogot 1999: 43). The second phase of incorporation started during the waning decades of old globalization with the Berlin Conference of 1884. This phase of incorporation was attained through direct colonialism and lasted until the era of decolonization in the 1960s, outlasting old globalization by about half of a century. The pillage of the continent during the era of the slave trade was devastating to African societies in terms of both human and economic considerations. However, the most fundamental and lasting changes on Africa's political and economic systems, cultures, institutions, and class structures took place during the period of nineteenthcentury (old) globalization. Africa's present political map and economic structures were formulated during the era of colonialism, which represented growing imperialist competition among European powers with the decline of British hegemony. Africa's place in the global division of labor was also sealed during this phase. Moreover, in most cases, the departing colonial state created the post-colonial African state in its own image. The African state inherited the colonial state's extractive institutions and repressive security apparatus (Young 1994; Musah 2000; Acemoglu, Johnson, and Robinson 2001). Like the colonial state, it also operated essentially as an extroverted enclave isolated from the traditional institutions and cultural values and even interests of its constituency. 
The third phase of Africa's incorporation into the global system took place during the interlude between old and new globalization - the three decades between the beginning of the continent's decolonization in the early 1960s and the end of the Cold War in 1991. Decolonization marked the loosening of the monopolistic grip on African economies by their European colonial powers, resulting in some diversification of the trading partners of African countries. Despite the limited opportunities the third phase created, various factors undermined attempts by African countries to develop their own development strategies and to reconstitute the terms of their integration into the global system. The rivalry between the two ideological camps often denied African countries the independence necessary to chart their own development strategies, and the rival powers often used them as battlegrounds for proxy wars. Civil wars in the Congo, Mozambique, Angola, and Ethiopia are the most obvious examples. Given the political and economic structures of African countries, the post-World War II global economic system also continued to perpetuate the fragmentation of their economies by maintaining old links between former colonial powers and the resource-rich enclaves, at times through military intervention, as in the Congo in the early 1960s.

The internal contradictions of the post-colonial African state was another critical factor that hindered the ability of African countries to chart their own development strategies and redefine the terms of their integration into the global system. As a product of the anti-colonial social struggle, the postcolonial African state, no doubt, embodies goals of liberating its population from external domination. However, its failure to change fundamentally the structures of the state, which were designed by colonialism to oppress and exploit, has not allowed the post-colonial state to become an agent of empowerment of its constituency. With few exceptions, such as in Botswana and Mauritius, and South Africa to some extent, the state has remained largely outside the control of citizens and has, as a result, failed to reconcile its governance system with the traditional institutions of governance, cultural values, and interests of its citizens and thereby to transform the fragmented institutions of governance established under colonialism. Most African countries are, thus, characterized by duality and incoherence of institutions of governance. In the absence of a fundamental transformation and synergy between state and society and traditional and modern institutions, the postcolonial state is often seized by dictators who advance their own interests at the expense of broad social interests.

Independence from the influence of the citizenry allowed many African leaders to engage in gross corruption and to behave as if they owned the state. Mobutu of Zaire, Idi Amin of Uganda, Bokassa of the Central African 
Republic, Macias Nguema of Equatorial Guinea, Mengistu Hailemariam of Ethiopia, Abacha of Nigeria, and Taylor of Liberia are conspicuous examples. These dictators essentially privatized the state and used its coffers as their private bank accounts and its security forces as their private armies (Economist, 11 May 2000). Such conditions led to the characterization of the African state as 'state without citizens' or the 'vampire' state by some observers (Ayittey 1998; Ayoade 1998). Others characterized the African political landscape as a politics of clientelism or patrimony (Clapham 1982; Jackson and Rosberg 1982; Callaghy 1984).

Segments of the counter elite (elite not in power), also often saw the state as a prize to be won in order to get access to the privileges of power. Rebellions, such as those led by Jonas Savimbi in Angola and Foday Sankoh in Sierra Leone, were clearly inspired by a blatant drive to capture state power for self-serving purposes. Many of the military coups that took place in Africa between the late 1960s and the early 1980s were also motivated by similar, if less conspicuous, private ambitions. Often, leaders of opposition parties and armed rebel groups in post-Cold War Africa have also been driven by the same goals. The peace plans proposed by various mediators in efforts to settle current intra-state conflicts in the continent, including those in the Côte d'Ivoire, the Sudan, Burundi, and the Democratic Republic of the Congo, also center on power-sharing arrangements designed to incorporate rebel leaders into the power structure. Such plans, as important as they are in stopping devastating wars, pay little attention to broad social interests (Mengisteab 2004). The intensity of election disputes such as those that occurred in Togo, Ethiopia, and recently in the Democratic Republic of the Congo also reveals that retention of and access to the privileges of power rather than commitment to public service frequently motivates the contestants, who rarely shy away from politicizing ethnicity and risk undermining the fragile process of state- building in their countries.

Even nationalist leaders who were not viewed to be blatantly self-serving, such as Kwame Nkrumah of Ghana, Jomo Kenyatta of Kenya, Kenneth Kaunda of Zambia, Sekou Toure of Guinea, Julius Nyerere of Tanzania, Leopold Senghor of Senegal, and Houphouet Boigny of the Côte d'Ivoire, did not bring the state under the control of citizens. To the extent that these leaders differed from the self-serving dictators, the manner in which they governed was largely an expression of their own vision and sense of benevolence rather than the expressed wishes of their populations. The unpopularity of Ujaama in Tanzania or many of Nkrumah's policies in Ghana, including the outlawing of opposition parties, are examples. 
The identified contradictions in the nature of the African state and the discrepancy between popular expectations and the interests of the ruling elite did not allow Africa to take full advantage of the openings the global system presented during the interlude between old and new globalization. Nevertheless, the Cold War-era rivalry between the superpowers and the global Keynesian welfare state ideology of compromise between social classes, which prevailed during that era, facilitated the success of nationalist movements in decolonizing African countries. The Cold War-era global system, along with GATT's preferential treatment rules, which allowed promotion of infant industries, also enabled some African countries, especially those with relatively more benevolent leadership, including Kenya, the Côte d'Ivoire, and Senegal, to initiate some level of industrialization behind protectionist policies and to expand public services, such as education and healthcare, to their populations in the 1960s and early 1970s. Such changes, in turn, facilitated a modest level of diversification of African social classes. Easterly (2001) suggests that the 1960-79 period, which saw the median growth rate of per capita income in LDCs rise to $2.5 \%$, was an unusual era for LDCs while the 1980-98 stagnation, when the median growth rate fell to $0.0 \%$, represents a return to the historical pattern of divergence between rich and poor countries. His observation depicts Africa's experience rather well.

\section{New globalization and state-society relations in Africa}

The fourth phase of Africa's incorporation corresponds with the advent of new globalization at the end of the Cold War. The crisis of socialism and the collapse of the Soviet Union marked the emergence of a uni-polar global configuration of power with a homogenizing global ideology of liberalism. These changes marked a significant modification of the Cold War era-terms of incorporation of African economies into the global system. With new globalization, retrenchment of state involvement in economic activity, along with policies of liberalization that foster openness of the economy, including removal of protectionist measures, and deregulation of exchange rates, interest rates, and capital mobility, have become conditions for the integration of African and other developing economies into the global economy. These measures were imposed on developing economies as conditions for obtaining loans and aid, while the advanced economies, which have the power to make the world market work to their advantage, maintain their benefit from non-market advantages, such as subsidies and other forms of protectionism.

Crippled by the debt crisis, which was caused by a variety of factors, including the oil crisis of the 1970s, falling prices of primary commodities, worsening terms of trade, and mismanagement, African countries often 
reluctantly succumbed to pressures by the International Monetary Fund, the World Bank, and donor countries to adopt liberalization policies.

The impacts of new globalization on African economies have been highly controversial. Four different views can be identified. Proponents of globalization contend that liberalization by freeing the economy from state inefficiencies promotes faster growth and diversification of the economy and, thereby improves human conditions and fosters political stability (World Bank 1994). A polar opposite view contends that new globalization is a form of imperialism with polarizing expansion and subordination of the interests of developing countries to those of the advanced countries (Bienefeld 1994; Amin 2001; Petras and Veltmeyer 2001). A third view attributes the problems of de-industrialization, rising poverty, and inequality in Africa to globalization's liberalization programs without linking globalization to an imperialist design (UNECA 1989; Bentsi-Enchill 1992; Adepoju 1993; Kawewe and Dibie 2000; Mkandawire and Soludo 2003). A fourth view is highly skeptical of the claim of positive relationship between the adjustment programs and economic growth without necessarily attributing broader economic problems to the adjustment mechanisms (Przeworsky and Vreeland 2000; Easterly 2001, 2005; Barro and Lee 2002).

Disentangling the effects of globalization mechanisms from the influences of other factors has proven difficult (Soludo 2003). Factors that may be fully or partly exogenous to the globalization mechanisms, such as civil strife, can obviously undermine the effectiveness of globalization mechanisms in attaining their stated goals. Some of the influences of such variables, however, can be detected from the differential performance between countries that incurred civil strife and countries that did not. The data provided in Tables $1-5$, for example, show that the performance of countries with chronic conflicts, such as Angola, the Democratic Republic of the Congo, Liberia, Sierra Leone, and Somalia, was generally worse than those of most other countries. Factors, such as unfavorable or deteriorating terms of trade, and various forms of unfair trading practices by the advanced countries, that are largely beyond the control of individual African countries, can also undermine the effectiveness of globalization. Such adverse impacts, however, reveal deficiencies in the globalization mechanisms, which are expected to perform better than pre-globalization strategies in dealing with such adverse external conditions. The differential performance of African economies, through factors unrelated to globalization, also adds to the methodological complexity. Notwithstanding the sharp divergence of views and the methodological constraints, it is clear that after roughly two decades, globalization has not reversed Africa's dismal economic performance, which is described as 'the 
worst economic tragedy' of the twentieth century (Artadi and Sala-i-Martin 2003, 2004).

With the foregoing background, we now turn to the focus of the paper and examine how globalization has impacted on state-society relations and the nature of the African state, which is widely viewed to be responsible for the disjuncture between policy and broad social interests. More specifically, the rest of the paper explores two contrasting interpretations. The first is whether globalization strengthens society at large, thereby shifting the balance of power sufficiently in favor of society to enable it to reconstitute the state by transforming it from an imposed predatory entity, which sets policies with little regard for broad social interests, into an agent of social advancement that bases policy on social interests. The second is whether globalization helps to preserve the existing state-society disjuncture and the state's excessive extroversion, and thereby perpetuates the weak influence on policy by the general population outside the governing circle (henceforth civil society). As the previous section of the paper tried to argue, the predatory nature of the African state and the lack of coordination between policy and broad social interests have their roots in old globalization. The intention here is to examine if new globalization changes these conditions or perpetuates them.

The impact of globalization on state-society relations can be captured by examining changes in the level of influence of civil society on policy following the implementation of globalization mechanisms. Such changes, in turn, can be detected from the patterns of expenditures on public programs, especially those that constitute the most basic societal interests. The rationale is that if society's influence on policy-making and public spending priorities increases, such influence would lead to better coordination of policy with broad social interests, which, in turn, would be reflected in higher investments on the development of human capital and improvements in human conditions, compared to those of the self-serving predatory state.

It is difficult to determine what constitutes societal interests, as they vary from place to place and over time. In Africa's present socioeconomic context, however, they are very likely to include expansion of societal access to public services that enhance human capital, especially healthcare and education. Some studies have suggested that the prevailing low levels of primary school enrollment and low life expectancy, due to the pervasiveness of diseases, such as malaria, are important factors in the poor performance of African economies (Artadi and Sala-i-Martin 2003). It is estimated that malaria costs Sub-Saharan African countries between $5.8 \%$ and $17.4 \%$ of their annual gross national product. Health and educational services have become even 
more critical components of social interests following the HIV/AIDS epidemic. The HIV/AIDS epidemic is estimated to cost Africa between 11.7\% and $35.1 \%$ of GNP annually (Taylor and De Young 2003-4). Other aspects of broad social interests include; alleviation of poverty, increasing food availability, diversification of the economy to facilitate growth and job creation, and, of course, creation of a democratic system of governance with real representation for the general population. Changes in the identified indicators would give a reasonably good signal of changes in policy coordination with broad social interests.

The poor quality of data on African socioeconomic indicators is a concern since it can distort the detection of changes. However, if the quality of data can be expected to remain unchanged over the period of analysis, trends if not the precise level of changes can be detected with a reasonable level of confidence. Changes in policy coordination with social interests can be detected both from the side of allocation of resources and from the side of outcomes. However, absence of consistent and reliable data forces us to use either outcomes or allocation of resources for some of the indicators.

Policy changes in creating access to education can be estimated by comparing the ratio of expenditures on education to gross domestic product over time. It can also be measured by comparing the changes in the ratio of the population that has access to primary education, although access created by non-governmental agencies does not necessarily indicate a shift in policy. Access to healthcare can also be measured by the ratio of health expenditures to GDP and by health expenditures per capita and by the changes in life expectancy and child mortality rates. Food production and availability can be measured by the annual changes in total food production and by per capita calories intake, although food imports and food aid can affect this measure. Diversification of production can be captured in several ways. One way is to compare changes in the growth rates of the manufacturing sector and the changes in the share of the manufacturing sector to GDP. It can also be captured by comparing the changes in value added as percentage of GDP in the manufacturing sector. Changes in the levels of poverty are detected by the changes in the ratio of the population living on less than US\$1 a day, a widely used measure of poverty. Presence of a democratic system of governance would give a good indication of improvements in state-society relations. However, the presence of the formal institutions of democratic governance, such as multi-party systems and elections, does not necessarily capture the level of influence of society on policy, since elections can be conducted to recycle the elite in power without providing significant policy choices to the voters. African democratic institutions at the state level also 
remain shallow since they only nominally represent the peasantry, which constitutes the overwhelming majority of the population in most countries. The peasantry, of course, participates in voting but its interests are greatly underrepresented owing to the urban bias of the development approaches African countries pursue, and in many cases the peasantry continues to adhere to traditional institutions of governance.

\section{Access to education and healthcare services}

One aspect of the package of structural adjustment programs, which are used as globalizing mechanisms, is retrenchment of public expenditures. This policy is intended to reduce budgetary deficits, restrain the growth of money supply, and thereby establish the bases for stable prices and a climate conducive for investment. Obviously, a persistent large budgetary deficit would be unsustainable as it would lead to economic instability and undermine the development process. However, in the African case, where the level of human resources and infrastructure development are extremely low, there is widespread concern that austerity measures are likely to limit investments in these areas, thereby, impeding the long-term prospects for overall development.

Many Sub-Saharan African countries have retrenched their expenditures on public services since adopting adjustment mechanisms. Public expenditure on education has declined steeply in many countries, although modest increases are reported in a few cases. As depicted in Table 1, public expenditures on education as a ratio of gross national income (GNI) in the year 2000 declined in 13 out of 32 countries when compared with 1970 . The 2000 rates declined in 18 of 35 countries when compared with 1980 rates. They also declined in 26 of 42 countries when compared with the rates of 1990. For Sub-Saharan Africa in general, public expenditures on education as a ratio of GDP declined from 4.5\% in 1992 to 3.3\% in 1999 (World Commission on the Social Dimension of Globalization 2004).

Access to education as measured by the ratio of relevant age groups enrolled in elementary schools gives a mixed picture. Out of the 30 countries examined, the ratio of enrollment in elementary school in 1997 declined in 11 countries compared to the ratio of enrollments in 1980 (UNCTAD 2002). In five countries the changes were positive but the improvements were less than $5 \%$, and in 14 countries there was positive change but the change was too modest for a 17-year interval. Assessment of progress towards achieving the UN Millennium Development Goal of attaining universal primary education by 2015 also reveals that only 8 of 25 countries with data are regarded to be 
on track while 17 countries are either far behind or slipping back (African Development Bank 2002; Versi 2004: 17).

At a time when malaria and the HIV/AIDS epidemic are eroding the economic and social fabric of many African societies, total health expenditures as percentage of GDP show little effort by African countries to deal with the continent's growing health crisis. Compared to expenditures in 1990, total health expenditures (as ratio of GDP) in 2001 have declined or remained unchanged in 23 of 40 countries (Table 2). In six other countries, the change was $0.6 \%$ or less. Per capita expenditures in 2001 also declined in 23 of 39 countries and remained unchanged in one country (Table 2).

Budgetary stringency has also severely limited the capacity of many African governments to train health workers and to attract, retain, and maintain the moral of professional health workers (USAID 2003). A high rate of flight of health professionals, including doctors and nurses, to the advanced countries is a clear indication. The international Organization for Migration estimates that 23,000 African health professionals leave their countries every year, 'leaving their own stretched health service in dire straights' [sic] (All Africa.com 31 January 2005). Surveys estimate that $68 \%$ of health workers in Zimbabwe, 60\% in Ghana, 58\% in South Africa, 49\% in Cameroon, 38\% in Senegal, and $26 \%$ in Uganda want to leave their countries and migrate elsewhere (Liese and Dussault, 2004). When compared to figures from either the 1970s or 1980s, several Sub-Saharan African countries also experienced a decline in physicians per 100,000 of population in the 1990s (Liese and Dussault 2004). Child mortality rate as an indicator of availability of healthcare service also reveals that few African countries are making progress in extending healthcare to their populations. Only 8 of 48 sub-Saharan African countries are regarded to be on track to reduce mortality rates of children under the age of five years to a third of their 1990 level by 2015. Three countries are said to be slightly off track while 37 countries are far behind or slipping back (Africa Development Bank 2002; Versi 2004: 17). Life expectancy is another good indicator of availability of healthcare service. This indicator also reveals stagnation of the continent's healthcare system. The percentage of the population aged 60 years and above in 2002 declined or remained unchanged in 23 of 43 sub-Saharan African countries compared to those of 1992 (WHO 2002). 
Table 1: Public expenditure on education ( $\%$ of GNI)

\begin{tabular}{|c|c|c|c|c|c|c|}
\hline Country & 1970 & 1980 & Change & 1990 & 2000 & Change \\
\hline Angola & - & - & - & 4.4 & 4.4 & 0.0 \\
\hline Benin & 3.2 & 4.2 & 1.0 & 3.5 & 2.7 & -0.7 \\
\hline Botswana & 4.0 & 4.5 & 0.5 & 4.9 & 7.8 & 2.9 \\
\hline Burkina Faso & 1.8 & 2.1 & 0.3 & 2.2 & 1.4 & -0.9 \\
\hline Burundi & - & 2.6 & - & 3.3 & 3.1 & -0.3 \\
\hline Cameroon & 3.2 & 2.9 & -0.3 & 3.2 & 2.3 & -0.8 \\
\hline Cape Verde & - & - & - & 3.8 & 3.9 & 0.1 \\
\hline Central African Rep. & 3.6 & 3.7 & 0.1 & 2.2 & 1.6 & -0.6 \\
\hline Chad & 2.1 & 1.8 & -0.3 & 1.6 & 2.0 & 0.4 \\
\hline Comoros & 1.4 & 1.4 & 0.0 & 3.9 & 3.9 & 0.0 \\
\hline Congo Dem.Republic & 2.3 & 2.6 & 0.3 & 0.9 & 0.9 & 0.0 \\
\hline Congo Rep. & 5.7 & 6.6 & 0.9 & 5.8 & 6.5 & 0.7 \\
\hline Côte d'Ivoire & 4.7 & 6.1 & 1.4 & 6.8 & 4.5 & -2.3 \\
\hline Equatorial Guinea & - & - & - & 1.6 & 1.7 & 0.1 \\
\hline Ethiopia & - & - & - & 2.8 & 2.7 & -0.1 \\
\hline Gabon & 3.1 & 2.0 & -1.1 & 3.8 & 2.1 & -1.7 \\
\hline Gambia & 2.2 & 2.9 & 0.7 & 3.2 & 3.6 & 0.4 \\
\hline Ghana & 3.8 & 1.7 & -2.1 & 2.8 & 4.4 & 1.6 \\
\hline Guinea & - & - & - & 1.5 & 1.5 & 0. \\
\hline Guinea-Bissau & 0.6 & 4.0 & 3.4 & 2.7 & 2.7 & 0.0 \\
\hline Kenya & 4.7 & 6.2 & 1.5 & 6.4 & 6.1 & -0.3 \\
\hline Lesotho & 2.8 & 4.1 & 1.3 & 3.0 & 6.4 & 3.4 \\
\hline Liberia & 4.9 & 4.9 & 0.0 & - & - & - \\
\hline Madagascar & 2.9 & 3.7 & 0.8 & 2.0 & 1.8 & -0.2 \\
\hline Malawi & 3.4 & 2.6 & -0.8 & 2.5 & 3.8 & 1.4 \\
\hline Mali & 3.5 & 3.6 & 0.1 & 2.9 & 2.2 & -0.7 \\
\hline Mauritania & 3.2 & 5.0 & 1.9 & 4.5 & 3.7 & -0.8 \\
\hline Mauritius & 2.9 & 4.8 & 1.9 & 3.3 & 3.3 & 0.0 \\
\hline Mozambique & - & 3.8 & - & 3.8 & 3.7 & -0.1 \\
\hline Namibia & - & 1.5 & - & 6.7 & 8.4 & 1.7 \\
\hline Niger & 1.1 & 1.5 & 0.4 & 2.6 & 3.0 & 0.4 \\
\hline Nigeria & 1.5 & 2.2 & 0.7 & 0.8 & 0.8 & 0.0 \\
\hline Rwanda & 2.2 & 2.3 & 0.0 & 3.3 & 3.3 & 0.0 \\
\hline Senegal & 3.8 & 4.4 & 0.6 & 4.0 & 3.4 & -0.6 \\
\hline Seychelles & 3.8 & 5.5 & 1.8 & 8.1 & 6.1 & -2.0 \\
\hline Sierra Leone & 2.8 & 3.3 & 0.5 & 1.1 & 1.1 & 0.0 \\
\hline Somalia & 1.0 & 0.9 & -0.2 & 0.3 & - & - \\
\hline South Africa & 5.1 & 5.1 & 0.0 & 5.8 & 6.9 & 1.2 \\
\hline Sudan & 3.6 & 4.4 & 0.8 & 2.2 & 0.9 & -1.3 \\
\hline Swaziland & 4.2 & 4.6 & 0.3 & 4.8 & 6.5 & 1.7 \\
\hline Tanzania & - & - & - & 3.0 & 3.4 & 0.4 \\
\hline Togo & 2.0 & 5.4 & 3.5 & 5.2 & 4.3 & -0.9 \\
\hline Uganda & - & 1.1 & & 1.4 & 2.2 & 0.8 \\
\hline Zambia & 3.6 & 4.2 & 0.7 & 2.0 & 2.0 & 0.0 \\
\hline
\end{tabular}

Source: World Bank, 2002, World Development Indicators, Washington,.DC: World Bank. 
Table 2: Total expenditures on health, 1990/2001

\begin{tabular}{|c|c|c|c|c|c|c|}
\hline \multirow[b]{2}{*}{ Country } & \multicolumn{3}{|c|}{$\%$ of GDP } & \multicolumn{3}{|c|}{ Per capita in US\$ } \\
\hline & 1990 & 2001 & Change \% & 1990 & 2001 & Change $\%$ \\
\hline Benin & 4.4 & 4.4 & 0.0 & 17 & 16 & -1.0 \\
\hline Botswana & 6.2 & 6.6 & 0.4 & 155 & 190 & 35.0 \\
\hline Burkina Faso & 8.6 & 3 & -5.6 & - & - & - \\
\hline Burundi & 2.3 & 3.6 & 1.3 & 5 & 4 & -1.0 \\
\hline Cameroon & 2.8 & 3.3 & 0.5 & 26 & 20 & -6.0 \\
\hline Cape Verde & 6.6 & 3.7 & -2.9 & 48 & 57 & 9.0 \\
\hline Central African. Rep. & 4.2 & 4.5 & 0.3 & 18 & 12 & -6.0 \\
\hline Chad & 6.2 & 2.6 & -3.6 & 13 & 5 & -8.0 \\
\hline Comoros & 5.4 & 3.1 & -2.3 & 26 & 9 & -17.0 \\
\hline Congo Rep. & 3.9 & 2.1 & -1.8 & 6 & 5 & -1.0 \\
\hline Côte d'Ivoire & 3.4 & 6.2 & 2.8 & 28 & 41 & 13.0 \\
\hline Congo Dem. Rep. & 2.9 & 3.5 & 0.6 & 49 & 18 & -31.0 \\
\hline Equat. Guinea & 7.5 & 2 & -5.5 & 27 & 76 & 49.0 \\
\hline Ethiopia & 3.9 & 3.6 & -0.3 & 5 & 3 & -2.0 \\
\hline Gabon & 3.9 & 3.6 & -0.3 & 172 & 127 & -45.0 \\
\hline Gambia & 7.4 & 6.4 & -1.0 & 29 & 19 & -10.0 \\
\hline Ghana & 3.5 & 4.7 & 1.2 & 14 & 12 & -2.0 \\
\hline Guinea & 3.8 & 3.5 & -0.3 & 18 & 13 & -5.0 \\
\hline Guinea-Bissau & 8 & 5.9 & -2.1 & 16 & 8 & -8.0 \\
\hline Kenya & 4.3 & 7.8 & 3.5 & 16 & 29 & 13.0 \\
\hline Lesotho & 8.3 & 5.5 & -2.8 & 27 & 23 & -4.0 \\
\hline Liberia & 9 & 4.3 & -4.7 & 4 & 1 & -3.0 \\
\hline Madagascar & 2.6 & 2 & -0.6 & 7 & 6 & -1.0 \\
\hline Malawi & 5 & 7.8 & 2.8 & 11 & 13 & 2.0 \\
\hline Mali & 5.2 & 4.3 & -0.9 & 15 & 11 & -4.0 \\
\hline Mauritania & 3.8 & 3.6 & -0.2 & 20 & 12 & -8.0 \\
\hline Mozambique & 6 & 5.9 & -0.1 & 6 & 11 & 5.0 \\
\hline Niger & 4.9 & 3.7 & -1.2 & 16 & 6 & -10.0 \\
\hline Nigeria & 2.9 & 3.4 & 0.5 & 10 & 15 & 5.0 \\
\hline Rwanda & 3.7 & 5.5 & 1.8 & 11 & 11 & 0.0 \\
\hline Senegal & 3.8 & 4.8 & 1.0 & 30 & 22 & -8.0 \\
\hline Sierra Leone & 2.4 & 4.3 & 1.9 & 5 & 7 & 2.0 \\
\hline South Africa & 5.6 & 8.6 & 3.0 & 158 & 222 & 64.0 \\
\hline Sudan & 3.3 & 3.5 & 0.2 & 12 & 14 & 2.0 \\
\hline Swaziland & 7.1 & 3.3 & -3.8 & 70 & 41 & -29.0 \\
\hline Tanzania & 5 & 4.4 & -0.6 & 5 & 12 & 7.0 \\
\hline Togo & 4.2 & 2.8 & -1.4 & 19 & 8 & -11.0 \\
\hline Uganda & 3.4 & 5.9 & 2.5 & 6 & 14 & 8.0 \\
\hline Zambia & 3.2 & 5.7 & 2.5 & 14 & 19 & 5.0 \\
\hline Zimbabwe & 6.2 & 6.2 & 0.0 & 42 & 45 & 3.0 \\
\hline
\end{tabular}

Source: World Health Organization, 2003, The World Health Report 2003 and World Bank, 1999, Health Expenditures Services and Outcomes in Africa: Basic Data and Cross-National Comparisons, 1990-1996, July. 


\section{Levels of poverty}

The widespread outcry by critics about the disproportionate burden of the costs of adjustment on the poor prompted the sponsors of the globalization mechanisms to incorporate some poverty-alleviation measures to the adjustment programs (Cornia et al. 1987; ECA 1989). Despite the add-on measures, poverty as measured by the head count ratio has continued to increase in Africa. A comparison of the ratio of the population living on US\$1 or less per day for the years 1987-89 and 1997-99 in 24 Sub-Saharan states shows that the ratio of the destitute increased in 13 countries (Table 3 ). In two countries, the ratio declined by less than $2 \%$ and in 9 countries the ratio declined by more than 3\%. Adjusted poverty rates for Sub-Saharan Africa in general increased from 48\% in 1970 to $60 \%$ in 1995 (Artadi and Sala-iMartin 2003). The total number of the population living on less than US\$1 in Sub-Saharan Africa also increased, from 140 million in 1975 to 360 million in 2000 (Artadi and Sala-i-Martin 2003). According to the World Commission on the Social Dimension of Globalization (2004), the total number of the destitute increased from 241 million in 1990 to 323 million in 2000. An assessment of progress of African countries towards achieving the UN's Millennium Development Goal of reducing extreme poverty to half the 1990 level by 2015 also reveals that only 4 of 44 countries have achieved the goal and 9 countries are said to be on track while 31 countries are regarded to be slightly off, far behind, or slipping behind (Versi 2004: 17). Furthermore, the absolute poverty figure in the continent is expected to rise to 686.5 million people by 2015 (Yuri 2005).

In addition to sluggish economic growth, rising unemployment and cuts in state subsidies of food, education, and health are among the factors contributing to increasing the number of the poor. The rise in the number of the destitute has also been accompanied by rapid intensification of inequality in income distribution. The gini coefficient for Sub-Saharan African countries increased from 0.58 in 1970 to 0.65 in 2000 (Artadi and Sala-i-Martin 2003). On the basis of the identified evidence, it is reasonable to conclude that either poverty reduction has not been a high policy priority in much of Africa or that African countries are facing conditions that do not enable them to reduce poverty.

\section{Food production}

Food production is another area where the dissociation of policy from social interests is conspicuous. A comparison of growth rates of total food production and per capita calories intake in 33 Sub-Saharan states for the periods of 1980-90 and 1990-2000 shows that growth rates of total food production 
declined in 17 countries. In four countries the changes were positive but the difference was $0.5 \%$ or less. In 11 countries the difference was positive and greater than $1 \%$ (Table 4). A comparison of grnx $x$ th rates of per capita calories intake for the same two periods shows that the rates declined in 14 of the 31 countries. Poor performance in the two indicators shows that either little shift in policy in favor of food security has taken place or that policy shifts, if any, have not succeeded. Given that the poverty rates are greater in rural areas, where incomes of most people range from US\$0.33 to US\$0.80 a day (World Commission on the Social Dimension of Globalization 2004), the weak performance in the food sector also suggests that African governments have not taken serious policy initiatives to transform the subsistence sector of their economies. With growing global demand for African resources, many African states are also engaged in compulsory acquisition of communal land in order to grant concessions to corporations in the extractive industries. Often compensation to customary holders of such lands is either nonexistent or grossly inadequate. A growing number of people are evicted from their lands and condemned to poverty. Protectionist agricultural policies in rich countries have also contributed in undermining Africa's agriculture by making it difficult for African farmers to compete in the markets of those countries. Even more damaging to African agriculture is that subsidized agricultural exports from rich countries have driven African small farmers out of the domestic market and into subsistence farming.

\section{Diversification of production}

For proponents of globalization, openness through liberalization of trade allows the local opportunity costs of resources to be reflected more accurately. Decontrolling interest rates also raises the rates and encourages savings and the adoption of appropriate technology. Liberalization of capital mobility is also expected to stimulate foreign investment while privatization of banks is anticipated to allow banks to allocate funds to finance private investments in industry. However, each of these policies can also produce adverse results depending on the prevailing conditions. Lifting protectionist policies can, for example, lead to loss of revenue and the destruction of potentially competitive local infant industry by cheap imports. Higher interest rates and tight credit may also hurt industry, which tends to have higher working capital needs, while privatization of banks may discourage investments on industry, which tends to have longer duration and higher risks. High interest rates are also likely to discourage the formation and growth of small industries. Deregulation of capital mobility may also destabilize monetary systems, as they have done in several developing economies. 
Table 3: Share of population living on less than US\$1.00 a day

\begin{tabular}{lccc}
\hline & \multicolumn{2}{c}{ \% Total population } & \% Point \\
\cline { 2 - 4 } Country & $1987-9$ & $1997-9$ & difference \\
\hline LDCs with increasing export/GDP ratio and increasing GDP/capita: \\
Uganda & 57.6 & 41.5 & -16.1 \\
Cape Verde & 18.2 & 11.6 & -6.3 \\
Mozambique & 40.5 & 36.8 & -3.6 \\
Benin & 22.4 & 16.4 & -6.1 \\
Malawi & 76.2 & 55.8 & -20.4 \\
Ethiopia & 86.8 & 85.5 & -1.2 \\
Lesotho & 19.5 & 41.8 & 22.3 \\
Burkina Faso & 66.6 & 60.1 & -6.5 \\
Mali & 63 & 71.7 & 8.7 \\
\hline LDCs with increasing export/GDP ratio and decreasing or stagnant GDP /capita: & 14.1 & 0.8 \\
Senegal & 13.3 & 68.9 & 23.3 \\
Central African Republic & 45.6 & 81.6 & 2.5 \\
Chad & 79.1 & 80.9 & 25 \\
Guinea-Bissau & 56 & 46.7 & 4.5 \\
Madagascar & 42.2 & 76.4 & 11.8 \\
Comoros & 64.6 & 71.9 & 1.5 \\
Angola & 70.4 & & \\
\hline LDCs with decreasing & & & \\
\hline
\end{tabular}

LDCs with decreasing export/GDP ratio and increasing GDP/capita:

$\begin{array}{llll}\text { Mauritania } & 36.2 & 30 & -6.2 \\ \text { Guinea } & 71.5 & 64.1 & -7.4\end{array}$

LDCs with decreasing export/GDP ratio and decreasing or stagnant GDP/capita:

\begin{tabular}{llll} 
Gambia & 52 & 35.8 & -16.3 \\
Togo & 64.8 & 63 & -1.7 \\
Niger & 69.3 & 74.4 & 5.1 \\
Rwanda & 45.5 & 58.5 & 13.1 \\
Burundi & 60.2 & 71.2 & 11 \\
Sierra Leone & 30.2 & 67.4 & 37.2 \\
\hline
\end{tabular}

Source: UNCTAD, 2002, Escaping the Poverty Trap: The Least DevelopedCountries Report 2002, New York and Geneva: United Nations. 
Table 4: Food production and availability

\begin{tabular}{|c|c|c|c|c|c|c|}
\hline \multicolumn{4}{|c|}{ Total food production Average growth rates \% } & \multicolumn{3}{|c|}{ Per capita calories intake } \\
\hline Country & $1980-90$ & $1990-99$ & Change & 1980 & 1999 & $\%$ change \\
\hline Angola & 1.1 & 4.4 & 3.3 & 2134 & 1875 & -12 \\
\hline Benin & 5.4 & 5.3 & -0.1 & 2023 & 2489 & 23 \\
\hline Burkina Faso & 5.7 & 3.3 & -2.4 & 1671 & 2376 & 42 \\
\hline Burundi & 2.7 & -1.6 & -4.3 & 2022 & 1628 & -19 \\
\hline Cape Verde & 11.4 & 4.2 & -7.2 & 2556 & 3166 & 24 \\
\hline Central Af. Rep. & 2.4 & 3.6 & 1.2 & 2301 & 1978 & -14 \\
\hline Chad & 2.1 & 4.9 & 2.8 & 1646 & 2230 & 35 \\
\hline Comoros & 2.4 & 2.7 & 0.3 & 1784 & 1800 & 1 \\
\hline Congo Dem. Rep. & 3.3 & -1.3 & -4.6 & 2086 & 1637 & -22 \\
\hline Djibouti & 8.8 & -0.2 & -9.0 & 1733 & 2129 & 23 \\
\hline Equatorial Guinea & 1.5 & -0.7 & -2.2 & - & - & - \\
\hline Gambia & 0.7 & 2.3 & 1.6 & 1644 & 2598 & 58 \\
\hline Guinea & -0.8 & 4.1 & 4.9 & 2269 & 2133 & -6 \\
\hline Guinea-Bissau & 3.9 & 2.7 & -1.2 & 1898 & 2245 & 18 \\
\hline Lesotho & 1.9 & 0.8 & -1.1 & 2179 & 2300 & 6 \\
\hline Liberia & 0.9 & 2 & 1.1 & 2504 & 2089 & -17 \\
\hline Madagascar & 1.7 & 1.5 & -0.2 & 2374 & 1994 & -16 \\
\hline Malawi & 0.6 & 5.5 & 4.9 & 2246 & 2164 & -4 \\
\hline Mali & 2.1 & 2.6 & 0.5 & 1746 & 2314 & 33 \\
\hline Mauritania & 1.3 & 0.9 & -0.4 & 2118 & 2702 & 28 \\
\hline Mozambique & 0.1 & 5.4 & 5.3 & 1940 & 1939 & 0 \\
\hline Niger & -0.3 & 3.2 & 3.5 & 2139 & 2064 & -4 \\
\hline Rwanda & 0.8 & -2.2 & -3.0 & 2292 & 2011 & -12 \\
\hline São Tomé \& Príncipe & e -1.2 & 5.3 & 6.5 & - & - & - \\
\hline Senegal & 3.9 & 1.8 & -2.1 & 2207 & 2307 & 5 \\
\hline Sierra Leone & 1.7 & -0.7 & -2.4 & 2087 & 2016 & -3 \\
\hline Somalia & 1.8 & 1.9 & 0.1 & 1735 & 1555 & -10 \\
\hline Sudan & -0.7 & 5.8 & 6.5 & 2201 & 2360 & 7 \\
\hline Togo & 3.2 & 3.7 & 0.5 & 2281 & 2527 & 11 \\
\hline Uganda & 3.1 & 1.1 & -2.0 & 2056 & 2238 & 9 \\
\hline U R Tanzania & 3 & 0.8 & -2.2 & 2252 & 1940 & -14 \\
\hline Zambia & 4.1 & 0.9 & -3.2 & 2273 & 1934 & -15 \\
\hline All LDCs & 1.7 & 2.8 & 1.1 & 1888 & 2018 & 7 \\
\hline
\end{tabular}

Source: UNCTAD, 2002, Escaping the Poverty Trap: The Least Developed Countries Report 2002, New York and Geneva: United Nations. 
With trade liberalization, the level of tariff protection of import-substituting industries in Africa fell roughly between $30 \%$ and $50 \%$ over the period from the mid-1980s to the early 1990s (Oyejide 2003). The downward trend of tariff protection has continued since then. The optimistic expectations of proponents have not materialized, however. Instead, liberalization has exposed the industries of a number of African countries to significant losses through competition from cheap imports. The overall picture of Africa's industry since the implementation of liberalization policies has been rather grim. A comparison of manufacturing value added (as percentage of GDP) for the years 1990 and 1999 shows a decline in 23 of 30 countries while there was no change in 4 countries (Table 5). A comparison of value added as percentage of GDP for overall industry for 1990 and 1999 also shows a decline in 17 of 31 countries. A comparison of average annual growth rates of output in industry and in the manufacturing sector for the periods of 1980-90 and 1990-2000 also reveals a similar trend. In the manufacturing sector growth rates declined in 12 of 23 countries while growth rates in industry declined or remained unchanged in 15 of 29 countries (UNCTAD 2002). For SubSaharan Africa as a whole annual growth rates of value added in industry have declined from $2.2 \%$ for the $1975-84$ period to $1.7 \%$ for the $1985-89$ period and to $1.3 \%$ for the $1990-2000$ period (Table 6).

According to an UNCTAD study (2001), the elasticity of industrial value added with respect to GDP, which was 1.10 and 1.03 during the 1960s and 1970s respectively, declined to 0.75 for the 1980 s and 0.65 for the $1990 \mathrm{~s}$. Average annual growth rates of exports of manufactured goods also declined, from $44.3 \%$ for $1975-84$ to $30.9 \%$ for $1985-89$ and to $3.7 \%$ for the 1990-2000 decade (Table 6). Moreover, annual average gross national savings as percentage of GDP as well as annual average gross domestic investments as percentage of GDP have declined from $20.6 \%$ in $1975-84$ to $15.7 \%$ in 1985-89 and to $12.8 \%$ in 1990-2000 (Table 6). Average annual gross domestic investments as percentage of GDP for the 1985-2000 period are also lower than the pre-1984 years (Table 6). The ratio of private investments to public investments, however, has increased since the early 1990s (Artadi and Sala-i-Martin 2003), suggesting a modest shift in the balance of power between the state and a small capitalist class.

A number of factors have contributed to the stagnation of Africa's industry. Loss of market share to more established external competitors is one factor. The failure of globalization mechanisms to address some of the serious external constraints that African economies face is another factor. Among such constraints are Africa's limited access to the markets of developed countries, paltry foreign investment flows to Africa, and the continent's persistent unfavorable terms of trade, which have declined from 0.6 for the 
1974-84 period to -3.8 for the $1985-89$ years and to -0.5 for $1990-2000$ (World Bank 2002).

Table 5: Value added in industry and manufacturing ( $\%$ of GDP)

\begin{tabular}{|c|c|c|c|c|c|c|}
\hline \multirow[t]{2}{*}{ Country } & \multicolumn{3}{|c|}{ Industry } & \multicolumn{3}{|c|}{ Manufacturing } \\
\hline & 1990 & 1999 & Change & 1990 & 1999 & Change \\
\hline Angola & 41 & 77 & 36.0 & 5 & 4 & -1.0 \\
\hline Benin & 13 & 14 & 1.0 & 8 & 8 & 0.0 \\
\hline Botswana & 56 & 45 & -11.0 & 5 & 5 & 0.0 \\
\hline Burkina Faso & 22 & 28 & 6.0 & 16 & 12 & -4.0 \\
\hline Burundi & 19 & 17 & -2.0 & 13 & 9 & -4.0 \\
\hline Cameroon & 29 & 19 & -10.0 & 15 & 10 & -5.0 \\
\hline Central African Rep. & 20 & 20 & 0.0 & 11 & 9 & -2.0 \\
\hline Chad & 18 & 15 & -3.0 & 14 & 12 & -2.0 \\
\hline Congo Dem. Rep. & 28 & 17 & -11.0 & 11 & - & - \\
\hline Congo & 41 & 49 & 8.0 & 8 & 7 & -1.0 \\
\hline Côte d'Ivoire & 23 & 26 & 3.0 & 21 & 21 & 0.0 \\
\hline Ethiopia & 13 & 11 & -2.0 & 8 & 7 & -1.0 \\
\hline Gabon & 43 & 41 & -2.0 & 6 & 5 & -1.0 \\
\hline Ghana & 17 & 25 & 8.0 & 10 & 9 & -1.0 \\
\hline Kenya & 19 & 16 & -3.0 & 12 & 11 & -1.0 \\
\hline Madagascar & 14 & 14 & 0.0 & 12 & 11 & -1.0 \\
\hline Malawi & 29 & 18 & -11.0 & 19 & 14 & -5.0 \\
\hline Mali & 16 & 17 & 1.0 & 9 & 4 & -5.0 \\
\hline Mozambique & 18 & 25 & 7.0 & 10 & 13 & 3.0 \\
\hline Niger & 16 & 17 & 1.0 & 7 & 6 & -1.0 \\
\hline Nigeria & 41 & 33 & -8.0 & 6 & 5 & -1.0 \\
\hline Rwanda & 25 & 20 & -5.0 & 19 & 12 & -7.0 \\
\hline Senegal & 19 & 26 & 7.0 & 13 & 17 & 4.0 \\
\hline Sierra Leone & 20 & 27 & 7.0 & 4 & 4 & 0.0 \\
\hline South Africa & 40 & 32 & -8.0 & 24 & 19 & -5.0 \\
\hline Tanzania & 18 & 15 & -3.0 & 9 & 7 & -2.0 \\
\hline Togo & 23 & 21 & -2.0 & 10 & 9 & -1.0 \\
\hline Uganda & 11 & 18 & 7.0 & 6 & 9 & 3.0 \\
\hline Zambia & 49 & 24 & -25.0 & 14 & 12 & -2.0 \\
\hline Zimbabwe & 33 & 25 & -8.0 & 23 & 17 & -6.0 \\
\hline Sub-Saharan Africa & 34 & 29 & -5.0 & 17 & 16 & -1.0 \\
\hline
\end{tabular}

Source: World Bank, 2001, World Development Indicators 2001, Washington, DC: World Bank. 
The ever increasing debt burden is another factor, although recent donor agreements on debt relief for the highly indebted poor countries (HIPCs) may help some beneficiaries of the program. Sub-Saharan Africa's total external debt service payments (long-term loans and IMF credit) averaged $\$ 11,643$ million annually for the years 1990-2000. As Tshibaka (2003) notes, external factors play a significant, if not a leading, role in constraining the growth of African economies. The globalizing mechanisms, however, provide no protection from the external factors. By imposing unqualified openness on them, they are, in fact, likely to exacerbate the vulnerability of the continent's economies. In any case, neither Africa's agriculture nor its industry has responded positively to liberalization of trade, largely relegating the continent's production system to its traditional export of primary commodities. Improving commodity prices in recent years may improve growth rates of resource rich African countries. There is, however, little indication that such growth will be utilized to address poverty or to diversify the economy.

Table 6: Selected indicators of African economies

\begin{tabular}{|c|c|c|c|}
\hline Indicators & $1975-84$ & $1985-89$ & $1990-2000$ \\
\hline $\begin{array}{l}\text { Average annual } \% \text { growth } \\
\text { of value added in industry }\end{array}$ & 2.2 & 1.7 & 1.3 \\
\hline $\begin{array}{l}\text { Average annual } \% \text { growth } \\
\text { of value added in services }\end{array}$ & 3.1 & 2.5 & 2.4 \\
\hline $\begin{array}{l}\text { Average annual \% growth of } \\
\text { exports of manufactured goods }\end{array}$ & 44.3 & 30.9 & 3.7 \\
\hline $\begin{array}{l}\text { Average annual \% of growth } \\
\text { of export unit values }\end{array}$ & 6.0 & 3.6 & -0.5 \\
\hline $\begin{array}{l}\text { Average annual } \% \text { growth of export } \\
\text { of goods and non-factor services (real) }\end{array}$ & 0.9 & 2.7 & 4.4 \\
\hline $\begin{array}{l}\text { Average annual gross domestic } \\
\text { investment as } \% \text { of GDP }\end{array}$ & 20.8 & 15.3 & 16.7 \\
\hline $\begin{array}{l}\text { Annual average gross national } \\
\text { savings as } \% \text { of GDP }\end{array}$ & 20.6 & 15.7 & 12.8 \\
\hline Terms of trade & 0.6 & -3.8 & -0.5 \\
\hline $\begin{array}{l}\text { Total external debt service payments } \\
\text { in } \$ \text { millions current prices }\end{array}$ & 4,649 & 9,116 & 11,643 \\
\hline
\end{tabular}

Source: The World Bank, 2002, World Development Indicators 2001, Washington, DC, World Bank. 


\section{Institutions of democratic governance}

A more direct indicator of changes in state-society relations and in the level of influence of society on policy would be the development of a democratic system of governance that allows genuine representation of the general population in decision-making and allows the coordination of policy with broad social interests. Democratic regimes generally choose policies that are more favorable to the poor than undemocratic regimes (Acemoglu, Johnson, and Robinson 2003: 2). The influence of the general population in the ballot box through their numbers is likely to influence policy-makers in a democratic system to pay more attention to the needs and interests of the poor and the general population.

Proponents have credited globalization for the rapid spread of democracy worldwide. Most African countries, like many others in the poor regions of the world, have allowed modest freedoms of the press and allowed the establishment of multiparty political systems, partly through home-grown pressure, perhaps bolstered by the demonstration effect of democratization elsewhere in the world. Political conditionalities imposed by donors, who consider political liberalization essential for sustaining a functioning market system, are also factors contributing to political liberalization in the continent. Although often marred by irregularities, elections are now regularly conducted in most African countries. However, the data on the other indicators, such as poverty, do not show that democratization has shifted policy in favor of the population in Africa. In other words, the political liberalization measures, such as the institution of multiparty systems, elections, and relative freedom of the press have not yet translated into notable changes in public policy. Economic policies of regimes that came to power through election, such as those in Zambia, Kenya, and Malawi have also changed little from those of the regimes they replaced. In many countries the political reforms have also not been accompanied by independence of the judiciary, without which the rule of law cannot be firmly established.

As a result, some have viewed the democratization process in Africa as 'sham' largely undertaken by African leaders in order to meet the requirements of donors (Economist 2000). This view, however, tends to neglect the role of internal struggle for democratization that has taken place throughout the continent. The political reforms have also not been totally inconsequential. In several countries, including Senegal, Zambia, Ghana, Malawi, and Kenya, elections have resulted in regime changes. The political freedoms associated with such changes are also invaluable in themselves. Moreover, the political systems in several African countries, including South Africa, Botswana, 
Mauritius, Zambia, Tanzania, Kenya, Ghana, Mali, Benin, and Senegal can no longer be characterized as patrimonial or clientelist.

It is also possible that the political liberalization that has taken place can lead to conditions suitable for peaceful social struggle for policy coordination with broad social interest over time. Such an optimistic scenario is not very likely, however, given the contradictory impacts of globalization on democratization. Coordination of policy with broad social interests under a democratic system requires policy independence. By contrast globalization, as a development path imposed by the global hegemony, is inherently against policy independence. A report by the Copenhagen-based Centre for Development Research (1995: 66-7; Olukoshi 2003), for instance, notes that Structural Adjustment Programs have decreased the capacity of the African state, intensified Africa's aid dependency, and conditioned African societies to operate under an external 'policy command'. Furthermore, by strengthening the power of donor agencies, the transnational capitalist class, and the small local capitalist class over the rest of society, globalization weakens the forces of democracy that would coordinate policy with broad social interest. Globalization, thus, promotes democratization without self-determination in policy-making. A major risk of such deformed democratization is that African societies may lose confidence in the democratic system of governance and become more volatile and violent. A number of studies have emerged claiming that globalization reduces civil strife (Indra de Soysa 2001; Bussmann and Schneider 2003). African realities hardly support such claims as the occurrence of conflicts in the continent has risen since the early 1990s (Adedeji 1999; Newbury 2002; Human Security Center 2005).

\section{Conclusion}

The principal goal of the paper was to examine if globalization shifts the balance of power between the state and society in favor of society sufficiently to bring about the coordination of policy with broad social interests. Our analysis suggests that the impacts of globalization on state-society relations in Africa have been at best paradoxical. Two noteworthy changes have taken place with globalization. One is a relative strengthening of the private sector compared to the public sector. As noted earlier, the increase in the ratio of private investments to total investments at the expense of public investments suggests such a shift. If this shift continues, it may provide a segment of civil society, the capitalist class, an economic basis that would allow it to bolster its influence relative to the state as well as the rest of society. Such a development, in turn, may lead to some level of political pluralism. The second related development is the spread of some of the formal institutions of de- 
mocracy. However, as Sklar (1996: 39) notes, democracy implies the public management and nurture of markets so that they flourish with affordable fairness in the distribution of opportunities, services, and wealth. Democracy is expected to bring about such management of markets because it entails the empowerment of society at large to influence policy on access to social services and productive assets. Contrary to such expectations, the spread of the formal institutions of democracy has not narrowed the discrepancy between policy and social interests in the African case.

Political pluralism and freedoms of organization and press as ends in themselves are, of course, invaluable, even when not accompanied by the coordination of policy with social interests. A state that provides such liberties, as limited as they are, would be preferable over one that is repressive and authoritarian and does not coordinate resources with social interests. It is also possible that along with the expansion of the private sector of the economy the adoption of the institutions of democratic governance would gradually lead to the empowerment of civil society. The competition among political parties in conjunction with a freer press can, for example, lead to the expansion of political and economic space for civil society beyond the small capitalist class. This, in turn, may allow different civil society organizations to struggle through legal means for the narrowing of the gap between policy and social interests.

However, globalization has promoted two counter developments that may negate such possibilities. One development that undermines popular influence on policy is the external control of policy-making manifested by the conditionalities imposed on African states by the international financial institutions and donor countries. The conditionalities limit the sovereignty of African societies over development policy in general and public policy in particular. Another development is the shift in the balance of power within civil society in favor of a small capitalist class that can easily ally itself with the ruling elite and the external agents of globalization. Such a shift in the balance of power is not very likely to allow the development of popular democracy in which society at large would have a significant influence on policy. Globalization, under these conditions, is unlikely to facilitate the reconstitution of the African state or improve the coordination of policy with broad social interests. It is also likely that failure to bring about coordination of policy with broad social interests may exacerbate social unrest and political instability, which are capable of undermining both democratization and development. 


\section{References}

Acemoglu, Daron, Simon Johnson, and James Robinson, 2001, 'The Colonial Origins of Comparative Development: An Empirical Investigation', American Economic Review, 91 (December): 1369-1401.

Adedeji, Adebayo, 1999, 'Comprehending African Conflicts', in Adebayo Adedeji, ed., Comprehending and Mastering African Conflicts: The Search for Sustainable Peace and Good Governance, London: Zed Books, pp. 3-33.

Adepoju, Aderanti, 1993, The Impact of Structural Adjustment on the Population of Africa, London: UNFPA, Heinemann and James Currey.

African Development Bank, 2002, Achieving the Millennium Development Goals in Africa: Progress, Prospects, and Policy Implications (June).

Ake, Claude, 1996, Democracy and Development in Africa, Washington, DC: Brookings Institution.

Amin, Samir, 2001, 'Imperialism and Globalization', Monthly Review, 53(2)(June): 6-24.

Amnesty International, 2003, Amnesty International Report 2003.

Artadi, V. Elsa and Xavier Sala-i-Martin, 2003, The Economic Tragedy of the XXth Century: Growth in Africa, Discussion Paper \#0203-17, Department of Economics, Columbia University, New York (May).

Ayittey, George, 1998, Africa in Chaos, New York: St Martin's Press.

Ayoade, John A.A., 1985, 'State without Citizens: An Emerging African Phenomenon', in Donald Rothchild and Noami Chazan, eds, The Precarious Balance: State and Society in Africa, Boulder: Westview Press, pp. 100-118.

Barro, Robert and Jong-Wha Lee, 2002, 'IMF Lending: Who is Chosen and What Are the Effects?' Mimeo, Harvard University (April).

Bentsi-Enchill, Nii, 1992, 'NGOs Widen Anti-Adjustment Action', Africa Recovery, 6(3)(November): 26-27.

Bienefeld, Manfred, 1994, 'The New World Order: Echoes of New Imperialism', Third World Quarterly, 15(1): 31-48.

Bussmann, Margit and Gerald Schneider, 2003, "The "Peace Dividend" of Globalization: Foreign Economic Liberalization and Internal War', Paper presented at the 44th annual ISA convention, Portland, Oregon (25 February1 March).

Callaghy, Thomas, 1984, The State-Society Struggle: Zaire in Comparative Perspective, New York: Colombia University Press.

Centre for Development Research, 1985, Structural Adjustment in Africa: A Survey of the Experience, Copenhagen (March).

Chase-Dunn, Christopher et al., 1994, 'Hegemony and Social Change', Mershon International Studies Review, 38(2)(October): 361-376.

Clapham, Christopher, 1982, Private Patronage and Public Power: Political Clientelism in the Modern State, London: Pinter.

Cornia, G., R. Jolly, and F. Stewart, eds, 1987, Adjustment with a Human Face, 2 vols, Oxford: Clarendon Press. 
De Soysa, Indra, 2001, 'New World (Dis)Order? Testing the Effects of Trade and FDI on New Models of Civil Conflict, 1989-1999', Paper presented at ISA Meeting on Globalization, Hong Kong (26-28 July).

Easterly, William, 2001, 'The Lost Decades: Developing Countries' Stagnation in Spite of Policy Reform 1980-1998', Journal of Economic Growth, 6 (June): 135-157.

Easterly, William, 2005, 'What Did Structural Adjustment Adjust? The Association of Policies and Growth with Repeated IMF and World Bank Adjustment Loans', Journal of Development Economics, 76(1)(February): 1-22.

The Economist, 2000, 'The Heart of the Matter' (11 May).

Findlay, Ronald and Stanislaw Wellisz, 2003, The Theory of the State, Discussion Paper No. 0203-25, Department of Economics, Columbia University, New York (May).

Hardt, Michael and Antonio Negri, 2000, Empire. Cambridge, MA: Harvard University Press.

Human Security Center, 2005, The Human Security Report, 2005, University of British Columbia.

Jackson, Robert and Carl Rosberg, 1982, Personal Rule in Black Africa: Prince, Autocrat, Prophet, Tyrant, Berkeley: University of California Press.

Kawewe, Saliwe and Robert Dibie, 2000, 'The Impact of Economic Structural Adjustment Programs [ESAPs] on Women and Children: Implications for Social Welfare in Zimbabwe', Journal of Sociology and Social Welfare, XXVII(4) (December): 79-107.

Keller, Edmund J., 1991, 'The State in Contemporary Africa: A Critical Assessment of Theory and Practice', in Dankwart A. Rustow and Kenneth Paul Erikson, eds, Comparative Political Dynamics: Global Research Perspectives, New York: HarperCollins Publishers, pp. 134-159.

Liese, Bernhard and Gilles Dussault, 2004, The State of the Health Workforce in Sub-Saharan Africa: Evidence of Crisis and Analysis of Contributing Factors, Washington, DC: Africa Region, The World Bank.

Mengisteab, Kidane, 2004, Africa's Intrastate Conflicts: Relevance and Limitations of Diplomacy, African Issues, 32(1 \& 2): 25-39.

Mkandawire, Thandika and Charles Soludo, 2003, 'Introduction: Towards the Broadening of Development Policy Dialogue for Africa', in Thandika Mkandawire and Charles Soludo, eds, African Voices on Structural Adjustment, Trenton, NJ and Asmara, Eritrea: Africa World Press, pp. 1-15.

Musah, Abdel-Fatau and J. Kayode Fayemi, eds, 2000, Mercenaries: An African Security Dilemma, London: Pluto Press.

Newbury, Catharine, 2002, 'States at War: Confronting Conflict in Africa', African Studies Review, 45(1)(April): 1-20.

OECD, Economic Outlook 1997-2000.

Ogot. B.A., 1999, General History of Africa: Africa from the Sixteenth to the Eighteenth Century, Abridged Edition, Paris: UNESCO. 
Olukoshi, O.A., 2003, 'The Elusive Prince of Denmark: Structural Adjustment and the Crisis of Governance in Africa', in Thandika Mkandawire and Charles C. Soludo, eds, African Voices on Structural Adjustment, Trenton, NJ and Asmara, Eritrea: Africa World Press, pp. 229-273.

Oyejide, Ademola, 2003, 'Trade Liberalization, Regional Integration, and African Development in the Context of Structural Adjustment', in Thandika Mkandawire and Charles C. Soludo, eds, African Voices on Structural Adjustment, Trenton, NJ and Asmara, Eritrea: Africa World Press, pp. 73-101.

Petras, James and Henry Veltmeyer, 2001, Globalization Unmasked: Imperialism in the 21st Century, Halifax, Nova Scotia and London: Fernwood Publishing and Zed Books.

Przeworski, A. and J.R. Vreeland, 2000, 'The Effects of IMF Programs on Economic Growth', Journal of Development Economics, 62: 385-421.

Robinson, William, 2004, 'From State Hegemonies to Transnational Hegemony: A Global Capitalist Approach', in Thomas Ehrlich Reifer, ed., Globalization, Hegemony and Power, Boulder and London: Paradigm Publishers, pp. 54-73. Rupert, Mark, 2000, Ideologies of Globalization: Contending Visions of a New World Order, London and New York: Routledge.

Samatar, Ahmed and Abdi Samatar eds, 2002, The African State: Reconsiderations, Portsmouth, NH: Heinemann.

Silver, Beverly and Arrighi, Giovanni, 2005, 'Polanyi's "Double Movement": The Belles Epoques of British and U.S. Hegemony Compared', in Jonathan Friedman and Christopher Chase-Dunn, eds, Hegemonic Declines: Present and Past, Boulder and London: Paradigm Publishers, pp. 153-182.

Sklair, Leslie, 2006, 'Capitalist Globalization: Fatal Flaws and the Necessity for Alternatives', The Brown Journal of World Affairs, XIII(1) (Fall/Winter): 29-37.

Sklar, Richard, 1987, 'Developmental Democracy', Comparative Studies in Society and History, 23(4): 686-714.

Soludo, Charles Chukwuma, 2003, 'In Search of Alternative Analytical and Methodological Framework for an African Economic Development Model', in Thandika Mkandawire and Charles C. Soludo, eds, African Voices on Structural Adjustment, Trenton, NJ and Asmara, Eritrea: Africa World Press, pp. 17-71.

Taylor, Kate and Peter De Young, eds, 2004, Business and HIV/AIDS: Who Me? A Global Review of the Business Response to HIV/AIDS, 2003-2004, World Economic Forum and UNAIDS.

Tshibaka, Tshikala, 2003, 'Economic Policy Reforms, External Factors, and Domestic Agricultural Terms of Trade in Selected West African Countries', in Thandika Mkandawire and Charles C. Soludo, eds, African Voices on Structural Adjustment, Trenton, NJ and Asmara, Eritrea: Africa World Press, pp. 275-304.

UNCTAD, 2001, Economic Development in Africa: Performance, Prospects and Policy Issues. New York and Geneva: United Nations.

UNCTAD, 2002, Escaping the Poverty Trap: The Least Developed Countries Report 2002, New York and Geneva: United Nations. 
United Nations Economic Commission for Africa, 1989, African Alternative Framework to Structural Adjustment Programs for Socio-Economic Recovery and Transformation, Addis Ababa: UNECA, E/ECA/CM.15/6/Rev. 3.

United Nations Economic Commission for Africa, 2005, The Millennium Development Goals in Africa: Progress and Challenges, Addis Ababa, Economic Commission for Africa.

USAID, 2003, The Health Sector Human Resource Crisis in Africa: An Issue Paper, Washington, DC: United States Agency for International Development, Bureau for Africa, Office of Sustainable Development (February).

Versi, Anver, 2004, 'Formula for Africa's Rapid Growth', African Business (August) Wallerstein, Immanuel, 2004, The United States in Decline? in Thomas Ehrlich Reifer, ed., Globalization, Hegemony and Power, Boulder and London: Paradigm Publishers, pp. 19-34.

Waltz, Kenneth N., 1999, 'Globalization and Governance', PS: Political Science and Politics (December).

Western, Bruce, 1995, 'A Comparative Study of Working-Class Disorganization: Union Decline in Eighteen Advanced Capitalist Countries', American Sociological Review, 60: 179-201 (April).

Wood, Ellen Meiksins, 1998, 'Capitalist Change and Generational Shifts', Monthly Review, 5(5) (October).

World Bank, 1994, Adjustment in Africa: Reforms, Results and the Road Ahead, Washington, DC: World Bank.

World Bank, 1999, Health Expenditures, Services, and Outcomes in Africa: Basic Data and Cross-National Comparisons, 1990-1996, Washington, DC: World Bank (July).

World Bank, 2001, World Development Indicators 2001, Washington, DC: World Bank.

World Bank, 2002, African Development Indicators 2002, Washington, DC: World Bank.

World Bank, 2002, World Development Indicators 2002, Washington, DC: World Bank.

World Commission on the Social Dimension of Globalization, 2004, A Fair Globalization: Creating Opportunities for All, Geneva: International Labour Organization (24 February).

World Health Organization, 2002, The World Health Report, 2002, Rome: World Health Organization.

World Health Organization, 2003, The World Health Report, 2003, Rome: World Health Organization.

Young, Crawford, 1994, The African Colonial State in Comparative Perspective, New Haven and London: Yale University Press.

Yuri, Dikhavov, 2005, Trends in Globalization Income Distribution, 1970-2000 and Scenarios for 2015, Occasional Paper, UNDP Human Development Report Office, No. 2005/8. 
